\title{
Spatial Imagery in Translation: The Case of Rose Garden of Sa'di
}

\author{
Mahin Koochaki \\ M.A. student of translation studies \\ Mahin.koochaki@yahoo.com
}

Abbas Eslami Rasekh

Assistant Professor at the University of Isfahan

Doi: 10.5901/mjss.2013.v4n4p255

\begin{abstract}
This study investigates the way spatial situations are coded in the Persian Masterpiece "Rose Garden" written by Sa'di. In addition, as the manner in which they are adopted in translation is crucial for retaining the original spatial focus of meaning, this study concentrates on one of the English translations done by Edward Rehatsek (2000). In order to fulfill the purpose, spatial prepositions as smallest segments which could evoke the spatial point of view without requiring any other spatial-notion participants were detected in data and their spatial specifications were analyzed on the basis of their occurrence environment in Rose Garden. Lexicalization patterns of movement verbs as largest constituents that delineate spatial dimensions were extracted as well. Then, their translation counterparts were studied in order to determine in what forms the original spatial concepts were displayed in translation. Findings revealed that spatial prepositions in Rose Garden, in most cases, were alternatively used so as to convey more than one spatial meaning, so did English prepositions replaced in translation. Three lexicalization patterns designed for movement verbs were grouped under three categories as well on the basis of their demanding requirements including intransitive motion verbs, spatial prepositional phrases and transitive motion verbs. Same Patterns were replaced in translation, however with some degree of distinction.
\end{abstract}

Keywords: Figure, ground, spatial preposition $(S P)$, lexicalization pattern $(L P)$

\section{Introduction}

Literary authors deploy and manipulate linguistic devices in a manner and as much as that it suffices to achieve their ambition. One of properties observed in literary works is applying grammar for imposing and symbolizing particular ways of construing conceptual content (Langacker, 1999:46). Of cases in which syntactic structures are designed to code a cognitive concept are linguistic patterns evoking spatial imagery (Jansen, 2007: 281) i.e. the way in which relations between entities surrounding us are captured in terms of distance, proximity, horizontality, verticality, inclusion, exclusion, trajectories etc.

Linguistic structures and categories describing spatial dimensions have been studied by many scholars. Categorization of languages under verb-framed and satellite-framed languages (Talmy 2000 \&Kopecka, 2007), spatial conceptualization in children's and adults' language (Van Peer and Graph, 2002), spatial prepositions (Stosic, 2007) and lexicalization patterns of movement verbs (Slobin, 1999 and 2006, Cappelle\&Declerck, 2004, Jansen 2007) have been discussed in detail. Nevertheless, Persian spatial structures remained unstudied. Supposing that Persian utilizes similar linguistic properties as those of languages studied before to make spatial situations conceived, study in this regard is still required. It is because each language establishes different extent to which each linguistic pattern and device is assigned to encode the spatial specification.

Since this would be more challenging if literary masterpieces are taken into account, the present study focuses on one of Persian Masterpieces i.e. Rose Garden written by Sa'di, in which spatial structures are seen frequently amidst its stories in order to make moral advice as much palpable as possible. Accordingly, spatial prepositions (SPs) as smallest segments which could serve as spatial indication without requiring any other spatial participant are examined, along with lexicalization patterns of movement verbs (LPMV) as largest constituents in spatial constructions. Furthermore, as the manner in which spatial notions are communicated in the target text is significant to retain focus of spatial meaning as much accurate as possible, the same is studied in the English translation done by Rehatsek (2000). 


\section{Methodology}

In order to accomplish the objective of this study, prepositions having spatial sense were taken from Rose Garden and their meaning components were detected in compliance with their occurrence environment in the original. Furthermore, in order to group LP of movement verbs used in the original, three below categories were designed;

Category 1: the LP of movement verbs that contained intransitive movement verbs and noun phrases functioning concurrently as action doer and figure (i.e. moving entity)

Category 2: the construction that consisted of copular verb and spatial prepositional phrases

Category 3: the LP of movement verbs that included transitive movement verb, the noun phrase functioning as action doer, noun phrase regarded as figure/moving entity and other spatial prepositional phrases designating place of movement.

Then counterparts offered in translation were compared and contrasted with the original in terms of the extent to which they displayed spatial specifications and in terms of whether same or different linguistic categories were used to transfer the meaning concerned.

\section{Results \& Discussion}

In the present section, Rose Garden and the English translation are analyzed in compliance with the method specified above and the results for each characteristic of Persian and English counterparts are discussed.

\subsection{Semantic specificity of the SPS:}

\subsubsection{Towards sb/sth:}

Alternative prepositions were assigned to denote moving toward somebody or something. They could be distinguished from each other in relation to their participants or, in other words, their objects;

a. 'نزد' 'to': It referred to the fact that a person with so-called lower-social status or lower age went to a higher social status person. It also showed that a person went to another to ask for something or to complain about something.

b. 'يدئ 'to': It meant a person went to another person. Social status or age was not brought into focus.

c. 'u' 'to': It attributed to the fact that a person went to a place.

d. 'بر' 'on': It denoted that somebody or something moved harshly toward something or somebody else.

In translation, the spatial construction was omitted or was neutralized. Such options did not cause any serious loss as to transference of meaning in general because necessary indications were given by adjacent sentences. However, the spatial imagery was wiped out.In some cases, also, alternative prepositions to, before, into and among were used in order to transfer the meaning concerned and to act in compliance with the way English SPs were deployed in the original English spatial constructions.

\subsubsection{Over a surface:}

The prepositions' بر 'on' 'ر 'ر 'in' communicated the meaning of being located over the surface of an object. As the former was collocated with different objects, it was rendered by alternative options in, on and upon in order to fit with coming nouns. The latter was translated by upon and under, of which the second was exactly opposite to the original

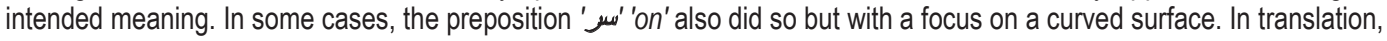
the prepositional phrase "on top of" was preferred over SP as in (1), retaining the spatial consideration.

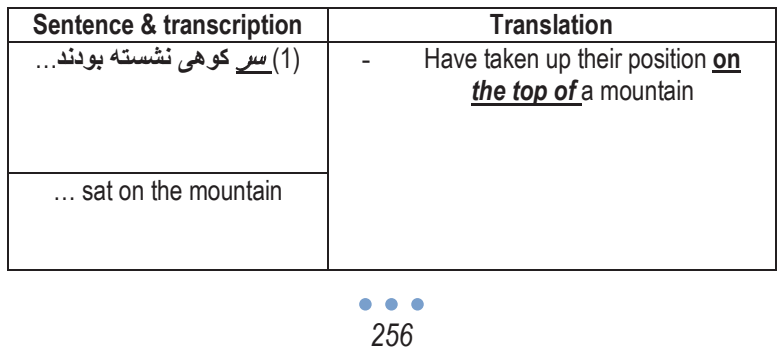




\subsubsection{Tip point of and handle of an object:}

The handle as well as the tip point of something was indicated by the same preposition i.e. ' 2 'on'. It was replaced with "the point of" and "the tip of", of which the former delineated a different meaning from that of original. As sentence (2) shows, 'سر' 'on' has the sense of the handle of the object i.e. sword. But, the translation option displayed the point of sword;

\begin{tabular}{|c|c|}
\hline Sentence \&Transcription & Translation \\
\hline (2) دست بكيردسر شمشير تيز & $\begin{array}{l}\text { - The hand grasps the point of the } \\
\text { sharp sword }\end{array}$ \\
\hline -He hold in his hand the handle of the sharp sword & \\
\hline
\end{tabular}

In translation of (3), a different option was put into force i.e. the original preposition and its object were conflated 1 into the noun phrase "wrist". This communicated the spatial meaning concerned, despite that the form in which it was rendered differed from that of the original;

\begin{tabular}{|c|c|}
\hline Sentence \&Transcription & Translation \\
\hline (3)به بازوان تواناو فتوت سر دست & $\begin{array}{c}\text { - With a powerful arm and the strength } \\
\text { of the wrist }\end{array}$ \\
\hline -With a powerful arm and the strength of tip of hand & \\
\hline
\end{tabular}

\subsubsection{Around the object:}

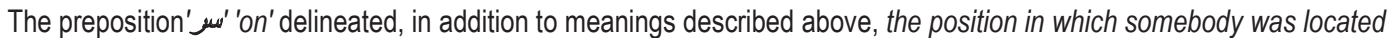
around the object or at a place as much near that he could touch its edge. It was omitted in order to fulfill the collocationrelated requirement, rendered by the preposition near or changed into the prepositional phrase. The preposition "near", among these counterparts, did not necessarily contain the meaning of "as much near as to touch the edge of the object or place concerned".

\subsubsection{Inside an object/ a place:}

SPs' لرن 'inside' contained the meaning of being located at a place. The former was replaced with in and into, transferring spatial sense of the original. Or, it was avoided in translation as in (4) in which the syntactic structure reordered so that no equivalent was required for ' $ر$ ' in'. This modulation² changed the spatial point of view although the general meaning was provided.

\begin{tabular}{|c|c|}
\hline Sentence \& transcription & Translation \\
\hline (4)به مجلس اومير كتاب شاهنامه همى خواندند & - The Shanamah $\theta$ was read in his assembly \\
\hline -In his assembly, in the book of Shahr & \\
\hline
\end{tabular}

\footnotetext{
1a general cognitive process at work in language whereby an event that under a more analytic conceptualization would be understood as complex and represented by a multi-clause syntactic structure can be alternatively conceptualized as simplex and represented by a single clause(Talmy19991:3)

${ }^{2}$ As shifting the original active sentence into the passive shows a variation through the change of viewpoint(Newmark, 1988:88), it is considered modulation.
} 
And the latter, which was distributed more in verse than prose lines of Rose Garden, was translated by in, into, amidst and among. These options were in compliance with the original meaning and the consideration of English over use of SPs.

\subsubsection{The point from which an action starts:}

The point from which the action concerned begins was realized by the preposition ' $j$ 'from'. It was rendered by from. However, in (5) the preposition along with its object was conflated in the phrasal verb divest of. This conflation made a shift of meaning as regards the spatial focus, however to a small extent.

\begin{tabular}{|c|c|}
\hline The sentence \& transcription & Translation \\
\hline (5) سلاح/زيتن بخشادند & \multirow[t]{2}{*}{ [They] divested themselves of their arms } \\
\hline They took their arms from their body & \\
\hline
\end{tabular}

\subsubsection{Instrument to make a motion\& harshness of motion:}

The preposition 'ب' 'to' attributed to the harshness of motion as well as to the instrument required for a motion. In translation, the meanings detected were retained by prepositions by and with respectively.

\subsubsection{The purpose of motion:}

The purpose for which a motion is done was coded by the preposition 'به' 'to'. The meaning considered was rendered by the preposition for. Or, the whole spatial construction was neutralized as in (6). Such treatment made the original spatial indication out of focus.

\begin{tabular}{|c|c|}
\hline Sentence\&Transcription & Translation \\
\hline (6)روستاز ادكان دانثمند بِ وزيربِادشاه رفتتد & $\begin{array}{c}\text { Learned sons of peasants became the viziers of } \\
\text { padshahs } \underline{\theta}\end{array}$ \\
\hline -Learned sons of farmers went to become viziers of the king & \\
\hline
\end{tabular}

\subsubsection{The foot of a place/an object}

The SP 'بإى' foot of' applied to signify the lower part of objects such as tree and throne placed on the floor by one or more legs. The meaning was realized by "at the foot of" and "near", of which the latter seemed to change meaning because it assigned a meaning of distance, even if near, from the foot of the object considered.

\subsubsection{Behind an object/in pursuit of something/somebody:}

The preposition ' 'behind' contained two meanings in Rose Garden: the back side of an object (e.g. paper) and the movement behind the entity concerned. In order to transfer these meanings, the translator used "on the back of" and "behind" respectively. Such options acted as what was spatially concerned in the original. However, the modulation applied in the rendition of (7) shows some variation as regards spatial perspectives;

\begin{tabular}{|c|c|}
\hline Sentence \&Transcription & Translation \\
\hline (7)سخان درقفاى وى افتادند & -He was attacked from behind by dogs. \\
\hline -Dogs were running behind him & \\
\hline
\end{tabular}

The other preposition attributed to movement behind the entity concerned was 'ئ' 'following'. It was rendered by "near", "in the rear of" and the verb "chase". The first option did not necessarily contain the meaning of behind. In other words, near conveyed the meaning of nearness in any side not just behind, hence causing some shift of meaning. The 
second option denoted the position at the back of entity considered, being in compliance with the original. The third contained the meaning of moving behind the entity concerned. However, as it had the sense of moving behind the entity to catch him, it was not considered accurate as to the occurrence environment indicated in the original i.e. a slave was running behind the king to be at his service;

\begin{tabular}{|c|c|}
\hline Sentence \& transcription & \multirow{3}{*}{ - A slave was just chasing him } \\
\hline (8) غلامى دريعيدوان & \\
\hline A slave was running behind & \\
\hline
\end{tabular}

\subsubsection{Under a surface:}

The preposition ' زي 'under' had the sense of the position under surface of the object concerned. "Under" taken in the translation could show the same spatial focus of meaning as that of the original.

\subsubsection{A higher position:}

The higher position was realized through the preposition 'ب̣' 'up'. It was replaced with "up" in translation. In translation of (9), "to", however, was used which did not transfer the meaning of the original. But, as the occurrence environment evoked the imagery that the person concerned went from a lower position (i.e. from boat) to an upper position (i.e. pillar), lack of "up" in translation did not cause any obvious lack of meaning.

\begin{tabular}{|c|c|}
\hline Sentence \&Transcription & Translation \\
\hline (9)او به بالاي ستون رفت & \multirow{2}{*}{ He went to the pillar. } \\
\hline He went up the pillar & \\
\hline
\end{tabular}

\subsection{LPs of movement verbs:}

\subsubsection{Subject Intransitive Verb (prepositional phrase) (Adverb of Motion):}

Sentences structured on the basis of this LP delineate spatial structure as follows: the action doer moves as a moving entity from a source across a path to the ground/endpoint. The main requirements here are subjects functioning as ground and motion verbs. Prepositional phrases and adverb of motions are augmented to the structure, where necessary. They were rendered by structures in which such indications were given. However, some subtle shift of meaning was observed. The sentence (10), for instance, means that the arrow is passing across the bow. But, in translation, the bow was considered a source from which the arrow started its movement.

\begin{tabular}{|c|c|}
\hline The sentence \& Transcription & Translation \\
\hline (10) ... تير از [ميان] كمان همى كنرد & \multirow{2}{*}{$\ldots$ The arrow is shot from the bow } \\
\hline The arrow is passing through the bow & \\
\hline
\end{tabular}

In (11), adverbs of motion 'مرامان' 'moving gently' and 'continuously' displayon their behalf the considered spatial scene. Such meaningswere conflated into the verb strut in translation. As mentioned before, the conflation made the original spatial meaning changed because the form by which the meaning was actualized was distinct to that of the original.

\begin{tabular}{|c|c|}
\hline The sentence \& Transcription & Translation \\
\hline [(11)او] خرامان همى رفت & \multirow{2}{*}{ [He] strutted about ... } \\
\hline -He went gently and continuously & \\
\hline
\end{tabular}


In (12), the adverb of motion 'همى' 'continuously'is again deployed. Moreover, the prepositional phrase 'ركبل 'in strap 'implied that a walking person had followed a riding person.This spatial scene was replaced with a general one, making the original indication blurred.

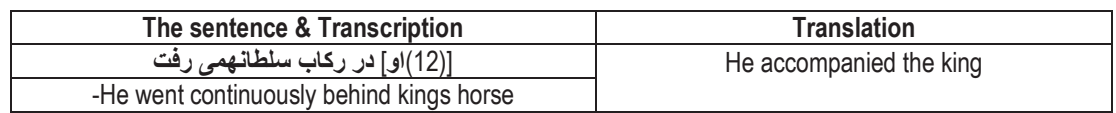

Some other participants were also in collaboration with intransitive verbs. For example, in (13), the infix''and the noun 'بنجه' 'finger'are augmented to the verb 'فكندن' 'to throw'. This combination means to fight with fingers against somebody else. It was rendered by the verb'wrestle'. Despite thatsuch an option retained the meaning in general, the focus on 'بنجִ' 'finger' wasblurred;

\begin{tabular}{|c|c|}
\hline The sentence \& Transcription & Translation \\
\hline (13)] من] با شير زُيان بِنجه در افككنم & \multirow{2}{*}[l]{... to wrestle with a furious lior } \\
\hline - I throw claw at a strong lion & \\
\hline
\end{tabular}

This was realized by the prepositional phrase with his fist in translation of (14);

\begin{tabular}{|c|c|}
\hline The sentence \& Transcription & Translation \\
\hline (14) هر كه با بولاد بازو ينجه كرد & \multirow[t]{2}{*}{ Who grasps with his fist one who has an arm of steel. } \\
\hline whoever throw finger at an steel arm & \\
\hline
\end{tabular}

The modification made to the subject could also perform some function as to spatial conceptualization. In (15), for

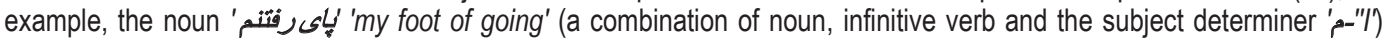
attributes to "not be able to walk", despite that a construction such as نمى توانستم بيشتر از اين راه بروم I" could not walk anymore" could be used instead. The sentence provided in translation delineated the meaning intended. However, the transposition applied made the intended meaning coded by the verb rather than subject.

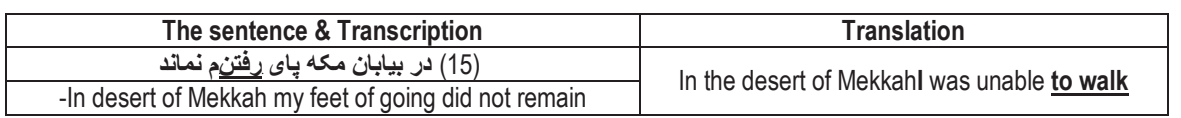

In (16), the figure ' ريش وكريبان 'beard and collar'comes first and the ground 'دست' 'hand' appears second. The modulation happened in translation created a re-ordered spatial structure i.e. hand was regarded as figure and beard as ground, thus changing the spatial viewpoint concerned. However, the general meaning was retained i.e. the young man took beard and collar.

\begin{tabular}{|c|c|}
\hline The sentence \& Transcription & Translation \\
\hline (16)ريش و كُيبان به دست جوان افتتاد & \multirow{2}{*}{ The young man's hand could reach the beard } \\
\hline Beard and collar fell into youth hand & \\
\hline
\end{tabular}

\subsubsection{Subject am/is/are/was/were subject predicative/prepositional phrases:}

Sentences formed with regard to this LP decoded the place where the entity considered was. Such a focus of meaning was rendered by similar counterparts as those of original i.e. subject plus copula verbs and prepositional phrases. The same construction was utilized in some cases to denote a general meaning of motion. The sentence (17) illustrated below is characterized as such. The spatial description was retained in translation;

\begin{tabular}{|c|c|}
\hline The sentence \& Transcription & Translation \\
\hline (17) آسيا سنى زيرين متحرى نيست & \multirow{2}{*}{ The nether millstone is immovable } \\
\hline -The lower millstone is not movable. & \\
\hline
\end{tabular}


Conversely, in (18), the subject predicate 'ناخن برنده تيز 'a tearing sharp nail' reached a maximum of harshness of motion and the same was rendered in the target sentence.

\begin{tabular}{|c|c|}
\hline The sentence \& Transcription & Translation \\
\hline (18)جون ندارى ناخن درنده تيز & \multirow{2}{*}{ If thou hast not a tearing sharp nail } \\
\hline If you has not a tearing sharp nail & \\
\hline
\end{tabular}

Two motions are described by the subject in (19) i.e. to attack the lion with fingers and to strike with fist at sword. They were deployed as examples in order to emphasize that intelligent men did not do unwise actions. The target options werein compliance with this intention;

\begin{tabular}{|c|c|}
\hline The sentence \& Transcription & Translation \\
\hline (19)ينجه بر شبير زدن و مشت بر شمشير كار خردمندان نيست & \multirow{2}{*}{$\begin{array}{l}\text { To strike one's fist on a lion and to grasp edge with } \\
\text { the hand is not the part of an intelligent man }\end{array}$} \\
\hline $\begin{array}{l}\text { - To attack the lion with fingers and to punch at the } \\
\text { sword is not the action done by the intelligent men. }\end{array}$ & \\
\hline
\end{tabular}

\subsubsection{SubjectVerb object (prepositional phrase) (Adverb of Motion)}

Unlike LPs examined in 3.2.1, transitive verbs in this LP provide the action doer and the figure together.In (20), for instance, 'كمترين اوج 'the smallest wave' and 'آسيا سنك 'the millstone' act respectively as the action doer and the figure. The same were considered in translation.

\begin{tabular}{|c|c|}
\hline Sentence \&Transcription & Translation \\
\hline (20) كمترين اوج آسيا سنى از كنارش در ربود & \multirow{2}{*}{$\begin{array}{l}\text { The smallest wave would whirl off a millstone from its } \\
\text { bank }\end{array}$} \\
\hline The smallest wave moved the millstone quickly from its side & \\
\hline
\end{tabular}

In (21), 'أنها' 'they' functions as the action doer and ' علام سياهو كنيز ' 'black slave and female slave' as the figure. The occurred modulation in translation caused a change in spatial focus i.e. the active-to-passiveshift and the omission of the action doer. In addition, "by their hands and feet" was added, which was not explicated in the original sentence;

\begin{tabular}{|c|c|}
\hline Sentence \&Transcription & Translation \\
\hline [(21) آنها]... غلام سياه را با كنيز محكم بيندند & \multirow[b]{2}{*}{$\begin{array}{l}\ldots \text { The negro and the girl to be firmly tied together by their } \\
\text { hands and feet }\end{array}$} \\
\hline -... To tie the black slave firmly to the girl & \\
\hline
\end{tabular}

Another modulation applied to (22). 'كنجى 'a treasure' and 't 'you' constitute the action doer and the figure respectively. Reordering the syntactic structure decreased spatial focus to the minimum extent or more precisely neutralized it.

\begin{tabular}{|c|c|}
\hline Sentence \&Transcription & Translation \\
\hline (22)كرد آيد تو را ... كنجى & \multirow{2}{*}{ Thou mayest accumulate ... a treasure $\underline{\theta}$} \\
\hline The treasure gather around you & \\
\hline
\end{tabular}

\section{Conclusion}

This study attempted to evaluate properties of spatial constructions in Rose Garden and their equivalents in the English translation. Findings could be summarized as follows:

1. Since two or more SPs were often utilized in Rose Garden tocarrysame spatial meaning, they were not preferred over each other in terms of the spatial specification, except for the preposition ' $\mathbf{s}$ ' 'at the foot of', 
'زير' under' and 'بالا' 'up'. English counterpartsdisplayed a similar behavior i.e. they were alternatively used in translation in order to communicate more than one spatial meaning.

2. Depending on whether the spatial description or the spatial interaction between entities was intended, LPs were constructed in Rose Garden. Spatial descriptions were decoded by following LPs:

a. Subject Intransitive Verb (prepositional phrase)(adverbs of motion)

b. Subject am/is/are/was/were subject predicative/ prepositional phrases

If the interaction between entities was aimed, the construction was formulated as follows;

c. Verb object (prepositional phrases) (adverbs of motion)

The basic structure for the case (c) was subject (action doer), verb (motion) and direct object (figure). Where necessary, other participants i.e. prepositional phrases and adverbs of motionwere augmented to the basic structure.

As regards translations of structures a, b, c, similar translation counterparts were often used. However, subtle shift of meaning was observed within target LPsin terms of the way smaller lexemes were treated. Some obvious distinctions happened also in translation, resulting from neutralization of the whole spatial constructionand use of general spatial constructions.Despite that the translation of adjacent clauses or other neighboring linguistic patterns could compensate for any loss of meaning in general, these options were regarded inaccurate as to the spatial perspective. In some cases, conflation was performed, which changed spatial emphasis as two or more spatial notions were expressed by a single linguistic category. Modulations as well caused the largest degree of spatially-inaccurate transference as they shifted spatial notions such as action doer to figure or vice versa.

It was, furthermore, demonstrated that small linguistic categoriesother than SPs were usedin Rose Garden too. For instance, theadverb of motion 'sیى' 'continuously' denoted a continuously slow movement. The other adverb used was' 'مرامان 'moving gently'attributed to the gentle motion. The former was rendered by continuous form of verb or was avoided and the latter was conflated in the target sentences.As indicated above, the omission and the conflation attenuated spatial significations.

Moreover, verb prefixes were deployed to designate some spatial notions. For instance, the prefix '-رلراز 'to come above' was used to display that the action doer sat or stood so as he was observed in a higher position than the other entity. The prefix' ردر' لراويختن'grapple with' and 'درافكندن"throw at' denoted that the entities approached each other as much near as they were stick to and grappled with each other. In translation, the meanings introduced were either neutralized orrealized by prepositional phrases.

\section{References}

Cappelle, B. \&Declerck, R. (2004). Spatial and Temporal Boundedness inEnglish Motion Events.Journal of Pragmatics 37(4).[Online] Available: www.sciencedirect.com(March 18, 2012).

Jansen, H. (2007). Construals in Literary Translation: Spatial Particles and Spatial Imagery.In Gambier\& Yves(eds.) Doubts and Directions in Translation Studies. Amsterdam: John Benjamins Publishing Company.

Langacker, R. (1999). Grammar and Conceptualization.Germany: Walter de Gruyter.

Kopecka, A. (2007).The Semantic Structure of Motion Verbs in French: Typological Perspectives. In Hickmann\& Robert (eds.) Space in Languages: Linguistic Systems and Cognitive Categories. Amsterdam: John Benjamins Publishing Company.

Newmark, P. (1988). A Textbook of Translation. US: Prentice Hall.

Rehatsek, E. (2000). The Rose Garden of Sa'di. Ames\& lowa: Omphaloskrpsis.

Šarić, L. (2008). Spatial Concepts in Slavic: a Cognitive Linguistic Study of Prepositions and Cases. Germany: Otto Harrassowitz Publication

Slobin, D. (1999). Two Ways to Travel: Verbs of Motion in English and Spanish. InShibatani\& Thompson (eds.) Grammatical Constructions: Their Form and Meaning. UK: Oxford University Press

Slobin, D. (2006). What Makes Manner of Motion Salient? In Hickmann\& Roberts (eds.) Space in Languages: Linguistic Systems and Cognitive Categories. Amsterdam: John Benjamin Publishing Company.

Stosic, D. (2007). The Prepositions par and à travers and the Categorization of Spatial Entities in French. In Aurnague\&Hickmann(eds.) TheCategorization of Spatial Entities in Language and Cognition.Amsterdam: John Benjamins Publishing Company.

Talmy, L. (1991). Path to Realization: A Typology of Event Conflation. Proceedings of the Seventeenth Annual Meeting of the Berkeley Linguistics Society: General Session and Para session on The Grammar of Event Structure. [Online] Available: www.elanguage.net/journals (March 18, 2012)

Talmy, L. (2000). Toward a Cognitive Semantics (I).US: MIT Press.

Van Peer, W. \& Graph E. (2002).Between the Lines: Spatial Language and its Developmental Representation in Stephan king's IT. InSemino\& Culpeper (eds.) Cognitive Stylistics: Language and Cognition in Text Analysis. Amsterdam: John Benjamins Publishing Company. 